\title{
Occupancy based architecture A case of traditional Savunese House in East Nusa Tenggara Province
}

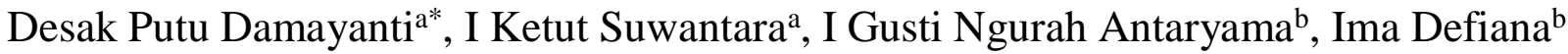 \\ ${ }^{a}$ Denpasar Experimental Station for Traditional Housing Technology Development, Research Institute For Human Settlement, \\ Ministry of Public Work, Indonesia \\ ${ }^{b}$ Department of Architecture, Sepuluh Nopember Institute of Technology, Indonesia \\ *Corresponding author. Tel.: 081238552598 \\ E-mail address: damabalaipu@gmail.com
}

\begin{abstract}
Many studies have concluded that traditional house works in close relationship with climate of a place. The studies also stated that building played an important role in determining the good indoor climatic conditions, but some of the study indicated that aside from the influence of building, occupant also governed the climatic performance. The present study closely investigated traditional Savunese house in East Nusa Tenggara-Indonesia, and was aimed to identify relationship of occupancy pattern with thermal condition of the building. Primary data were obtained from field observation and interview. These included indoor, outdoor air temperature, and occupancy pattern. Data obtained from BMKG (Meteorology, Climatology, and Geophysics Agency), representing average climatic condition of a ten-year period. The measurement of air temperature was done using Memory Hilogger, and observation and structured interviewed sheets were employed to record occupancy pattern. The study showed that during the dry season, the building was only experienced daily comfortable conditions for 14 hours (58\%). Out of these 14 hour comfortable conditions, $79 \%$ of the time occurred when the inhabitant were in the building. The study concluded that building elements were not the sole determinant of its good performance, but the way inhabitant occupied the house was also the contributor.
\end{abstract}

Keywords: traditional Savunese House; building performance; occupancy pattern; comfort; tropical building

\section{Introduction}

Passive design in traditional house commonly not using the active control to establish a comfort indoor temperature. An indoor temperature is a form of building design response to the micro climate. In the case of passive design, building performance expected can create a comfortable indoor temperature to optimize the indoor activities. Comfortable indoor temperature is a condition which the occupant does not need the effort of any kind to preserves the temperature of the body remains to $37^{\circ} \mathrm{C}$. That condition called by "neutral or comfort temperature".

Previous research shows that the duration of comfort temperature can be analyzed from a linear equation which influenced by an average monthly temperature. To evaluate the passive design performance, done by analyzing the result of daily temperature measurement. The secondary data about the average of monthly temperature is extracted from data Meteorology and Geophysics agency (BMKG). The length of duration comfort zone is an indicator of good building performance. Commonly, the change of indoor temperature of the traditional house is followed by the outdoor temperature change. This is because the construction of the traditional house is the type of lightweight construction. The lightweight construction can reduce indoor temperature lower than $1-2^{\circ} \mathrm{C}$ outdoor temperature. 
Measurement linear equation which using to determine the neutral temperature is $\mathrm{Tn}=17,6+0,31 \mathrm{x}$ Tav, while it range is $\mathrm{Tn} \pm 2^{\circ} \mathrm{C}$. Building comfort zone is a condition which indoor temperature enters in the range of neutral temperature. Longer duration of comfort zone created in one day that shows a better building performance. The similar study with traditional house cases indicates that comfortable duration happened during 11-12 hours/day. It happened from afternoon until the next morning day.

Similar studies related the performance of traditional buildings generally use the equation of liner. From the foregoing it was found that the duration of comfortable created only by $50 \%$ the time daily. Discovered the phenomenon when it only analyzes the duration comfortably created, and then the performance of traditional buildings is arguably poorly. This research aims to analyze the performance of House Ammu Hawu associated with occupancy patterns. If associated with a pattern of occupancy communities, the duration of thermal comfort occurs when the House was occupied.

This research evaluates the connectedness between duration of indoor comfort zone and duration of occupied. The case of study is Ammu Hawu traditional house in Savu Island - East Nusa Tenggara Province. The measurement done during the dry season and wet season. Daily temperature fluctuation of Ammu Hawu house measured digitally with a logger memory from Hioki.

\section{Method}

This research paradigm was an associative research. It is a research aimed at explaining the relationship of two variables or more. The result from an associate research usually is a novelty hypothesis for the future (Sugiyono, 2003). There were two variables analyzed in this paper, which was temperature and occupancy pattern. Both are the result of primary data measurement of the field. Temperature data consist of indoor temperature and outdoor temperature data. It measured by Memory HiLogger 8422-51 from Hioki. That logger connected by cable termokopel type $\mathrm{T}$ (sensor hot) for detected the air temperature. The data collected is the degree of air temperature in units of Celcius. The daily temperature profile obtained by the record of air temperature during 1 day. Air temperature calculated each 1-hour interval, during a minimum of 3 days ( $3 \times 24$ hours). The average temperature each hour during 3 days is a daily temperature profile. Time measurement conducted on the dry season an wet season. dry season and wet season determined from recording result of micro climate. The micro climate data of Savunese Raijua which collected is data recorded during the last ten years. That secondary data extracted from data Meteorology and Geophysics agency from Kupang Meteorology station (BMKG Kupang, 2012).

The other primary data that must be acquired is the pattern of occupant activity in Ammu house. The data were obtained through interview methods, it is aimed to find out the duration of the house occupied by the inhabitant. Existing data of Ammu Hawu design obtained from measurement field. Sketch field data are drawn repeated use Autocad software 2010.

Very much research method which can be used for determines a neutral temperature on passive design case. Neutral temperature is a condition of temperature which the respondent could not feel a hot or cold. It was created as a respond form of building from micro climate. Linear equation for determining the neutral temperature on a passive design is:

$\operatorname{Tn}=17,6+0,31 \times$ Tav

With the provision:

Tn : Neutral temperature $\left({ }^{\circ} \mathrm{C}\right)$

Tav : Averange of Monthly temperature $\left({ }^{\circ} \mathrm{C}\right)$

Average monthly temperature data is a secondary data about average of monthly temperature extracted from BMKG measurement data. 
The range of neutral temperature is $\mathrm{Tn} \pm 2{ }^{\circ} \mathrm{C}$. The area of neutral temperature called a comfort zone. Comfort zone have two levels, namely a lower comfort level $\left[\mathrm{Tmin}=\mathrm{Tn}(-) 2^{\circ} \mathrm{C}\right]$ an upper comfort level $[\mathrm{Tmax}=\operatorname{Tn}(+)$ $2^{\circ} \mathrm{C}$. While indoor temperature is lower than Tmin or higher than Tmax therefore, that condition categorized in the uncomforted zone. That profile is a description that occurs on daily time.

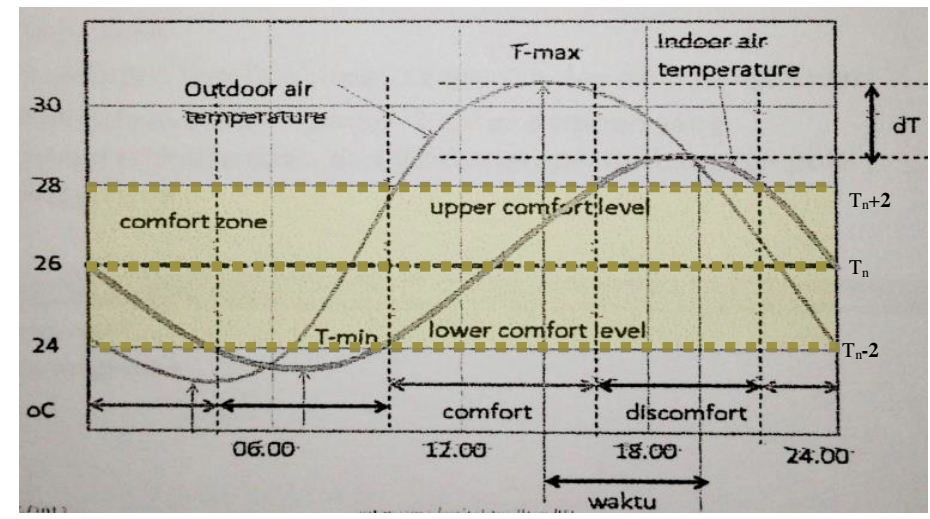

Fig. 1. Comfort-uncomfort zone in daily.

With the same methods the previously research, commonly revealed comfort duration and uncomforted duration resulting. The research has been not connected the duration of comfort zone with the duration of occupancy. Space theory revealed that occupancy pattern in a house is closely connected with activities of its inhabitants. Traditional society activities dominated by agriculture activities. Commonly, it start in the morning until afternoon at their rice field (outdoor activities), during 12 hours in a day. And then their house not occupied when the farming activities on going.

This research evaluates the connectedness between duration of indoor comfort zone to duration of occupant activity. Duration of occupancy data was obtained though field interview with occupants of the Ammu Hawu house (Fig.3).

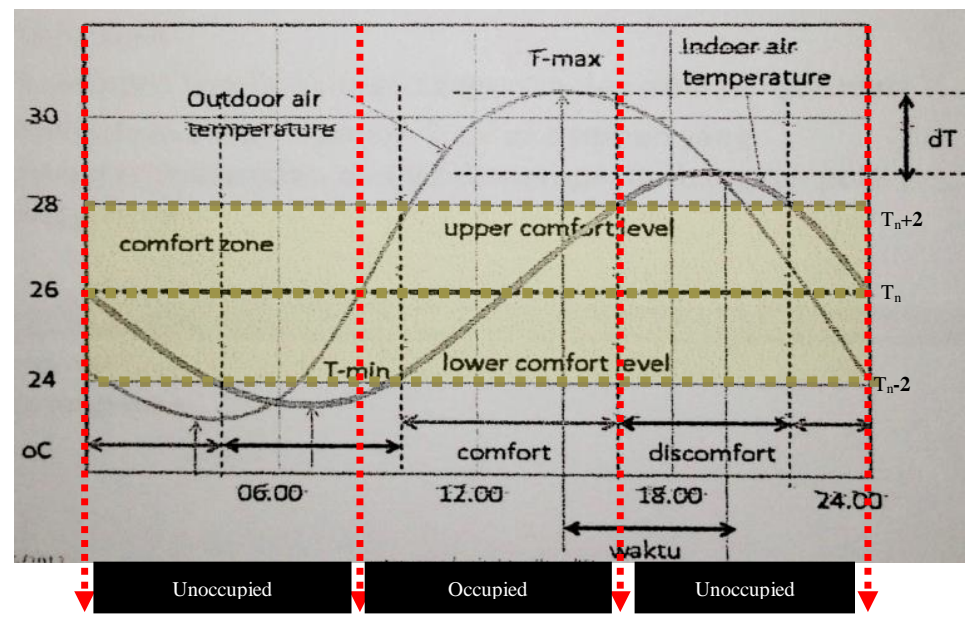

Fig. 2. Relationship of occupancy pattern with comfort zone. 


\section{Literature}

\section{Traditional Architecture of Savu}

East Nusa Tenggara Province has 10 variants of traditional architecture, analyzed from the aspect of building typology (Suprijanto \& Damayanti, 2009). Ten of these variants are : Sumba traditional architecture, Manggarai traditional architecture, Ngada traditional architecture, Ende traditional architecture, Lamaholot traditional architecture, Alor traditional architecture, Wehali traditional architecture, Atoni traditional architecture, Rote traditional architecture, and Savu traditional architecture (Fig. 3).

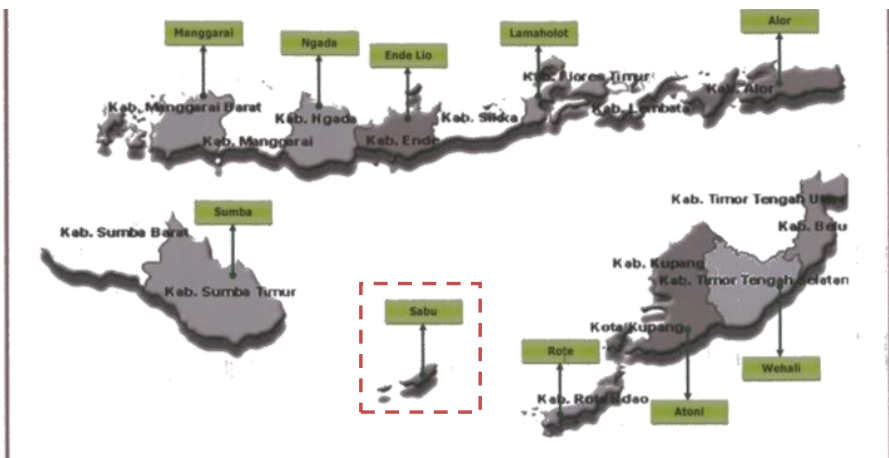

Fig. 3. 10 Variants of Traditional Architecture in East Nusa Tenggara Province (Suprijanto, Iwan \& Desak Putu Damayanti, 2009).

Characteristic of the traditional architecture Savu is visible from the morphological form. It is dominated by the roof area of the building (Damayanti, Kasuma, \& Suprijanto, 2013). The traditional savunese house is still be found in Savu Raijua Regency. Savu Raijua Regency is new otonom area which formed in 2008 (UU 52/2008, 2008). The regency was expansion result of Kupang regency. Coordinate point of Savu Rajua Regency is 10025'7,12"10049'45,83" South Latitude and 121016'10,78 - 12200'30,26" East Altitude. The difference in the value of the altitude effects on variation of climate environment. So the difference in environmental conditions will influence on the value of building thermal comfort (Brager \& de Dear, 2001; Humphreys \& Nicol, 2000). This island is bounded by Sawu sea in the North, East, and West side. South side of the island is bounded by the Indian Ocean. This research takes one of the traditional savunese house which located in the Namata Village, Savu Raijua Regency.

Savunese house is the stage house and have a structure system of taga stone. Taga stone structure beam connection system is a semicircular arch on both sides of the roof. Along with the growing need of space, Savunese house differentiated into two parts, namely Ammu Hawu and Ammu Java/foreign. Ammu Hawu consists of two types, Ати ae nga rukoko and Amu taga stone. Amu ae nga rukoko has a ridge jutting out, while Ammu taga stone doesn't have. While Ammu Java/foreign doesn't have taga stone (Table 1). The object of this research focus on Ae Nga Rukoko Ammu building (Damayanti et al., 2013).

Table 1.Types of Savunese House.

\begin{tabular}{lll|}
\hline \multicolumn{1}{c}{ Types } & Site Plan & Front View \\
\hline Ammu Ae \\
Nga Rukoko
\end{tabular}




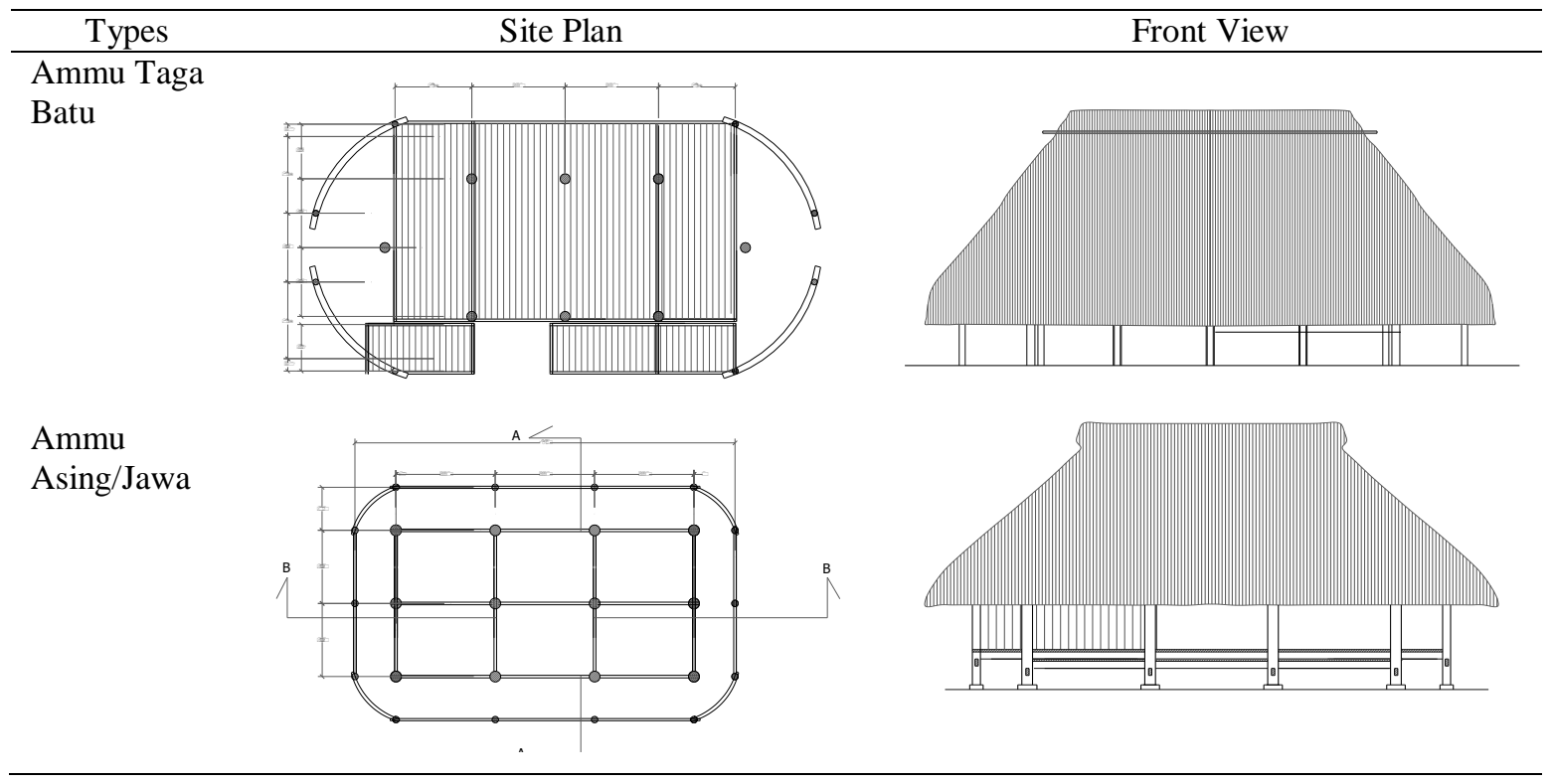

Savunese house dominated by a percentage of the area of roof, openings in the building ranges between 10$30 \%$. It is appropriate to get around the huge wind speeds. Taga stone on Amu ae nga rukoko serves as the influx of wind gap from the roof into the room. The community of approximately Savunese utilizes natural materials as building materials (Kana, 1978). Lontar leaf was chosen to cover the construction of the roof. Results of the fields study showed that the leaves is more "insulation" instead of palm leaves. That conductivity are low, making the leaf the epigraph transfer have good heat as material. It is able to absorb and release less heat from outdoors to indoors (Damayanti et al., 2013).

\section{Result and Disscusion}

\section{Macro Climate of Savu Island}

Micro climate condition in Savu Raijua Regency, obtained by secondary BMKG data. Monthly temperatures recorded during the last 5 years (Figure 4). The average annual temperature is reached $27,99^{\circ} \mathrm{C}$. The highest temperatures occur in November reached $30^{\circ} \mathrm{C}$. While, the lowest temperatures occur in July reached $26,32^{\circ} \mathrm{C}$ (Fig. 5). Smaller radiation on drought will cause a decline in temperatures and increased air pressure (Anderson et al., 1972). A decrease in temperature and an increase in air pressure will increase the speed of the wind (Machon, 2007). Because solar radiation is reduced, then the relative humidity will increase (Handoko, 1993). 


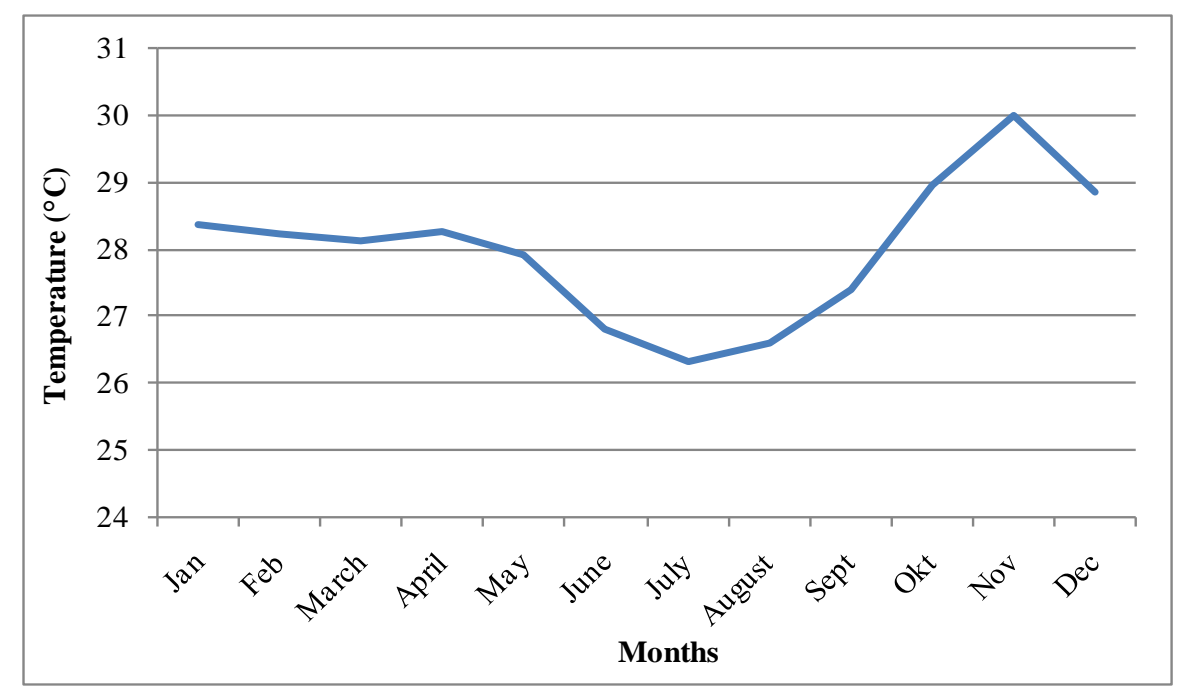

Fig.4. The monthly average temperature during the year.

The Savu outside environment has an extreme character. The sun shines an average annual reaches $80 \%$, so that the necessary building design that is able to inhibit the propagation of heat into the room. The other climate elements that make the outside environment on Savunese uncomfortable was the degree of humidity reached $75 \%$. Rainfall in the area is also low enough that is average reaching $92 \mathrm{~mm}$. However, the wind speed is high enough reach $128 \mathrm{~m} / \mathrm{s}^{2}$ (BMKG Kupang, 2012). The high wind speeds help to remove heat from indoors, but it takes a strong building construction in order not easily damaged by the force of the wind.

\section{Physical Characteristic Of Ammu Hawu}

Field observations indicate that Ammu Hawu not unlike the variety traditionally buildings in General. Ammu Hawu belongs in the category of home staging. Extensive roof Ammu Hawu dominate vast sheath the building (50\%). But the physical identity of the traditional building does not stop only on the roof only. The buildings traditional Ammu Hawu also has a hollow floor and wall coverings made from woven bamboo or wooden board arrangement. Description of primary data about Ammu Hawu is seen in Table 2.

Table 2.Primary Data Of Ammu Hawu House.

$\begin{gathered}\text { Component of Savunese } \\ \text { house }\end{gathered}$
First floor view


Second floor view

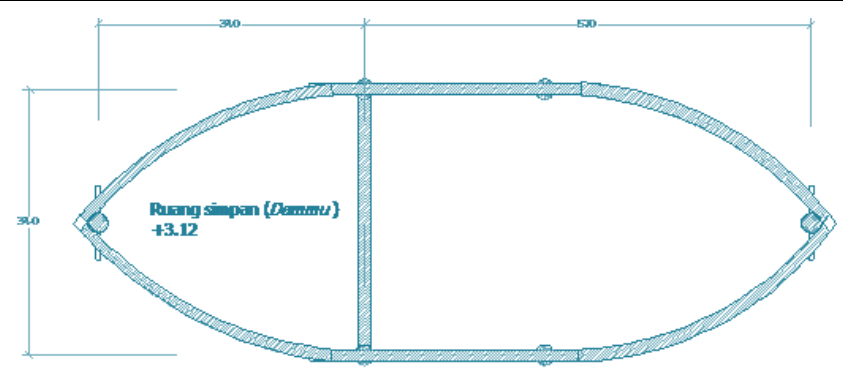

Front view

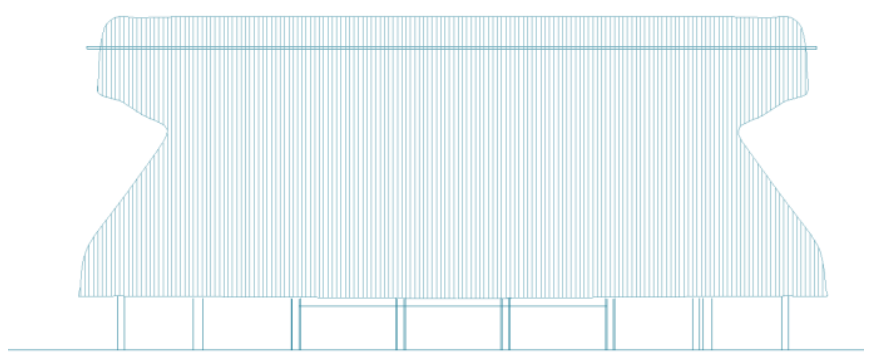

Section Plan
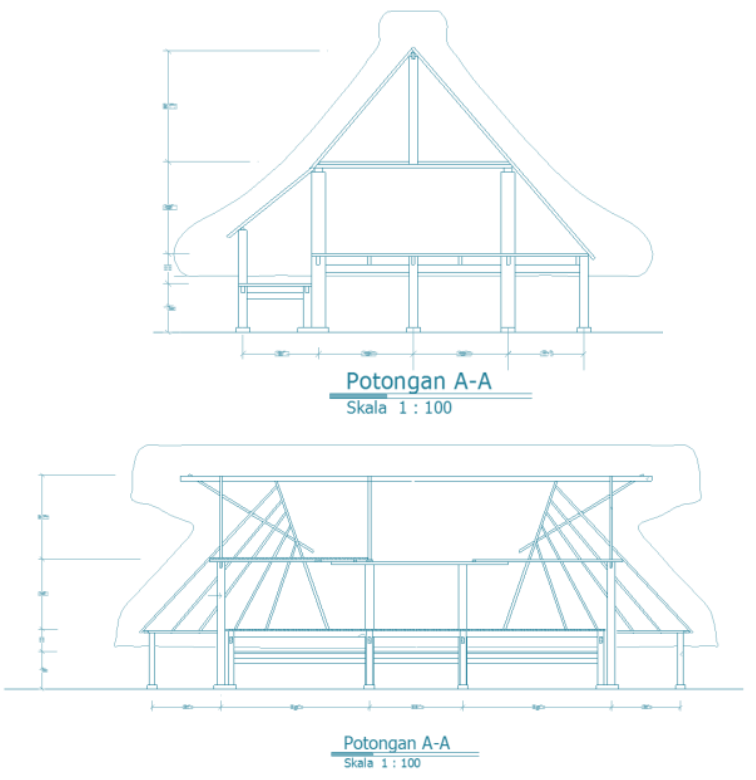


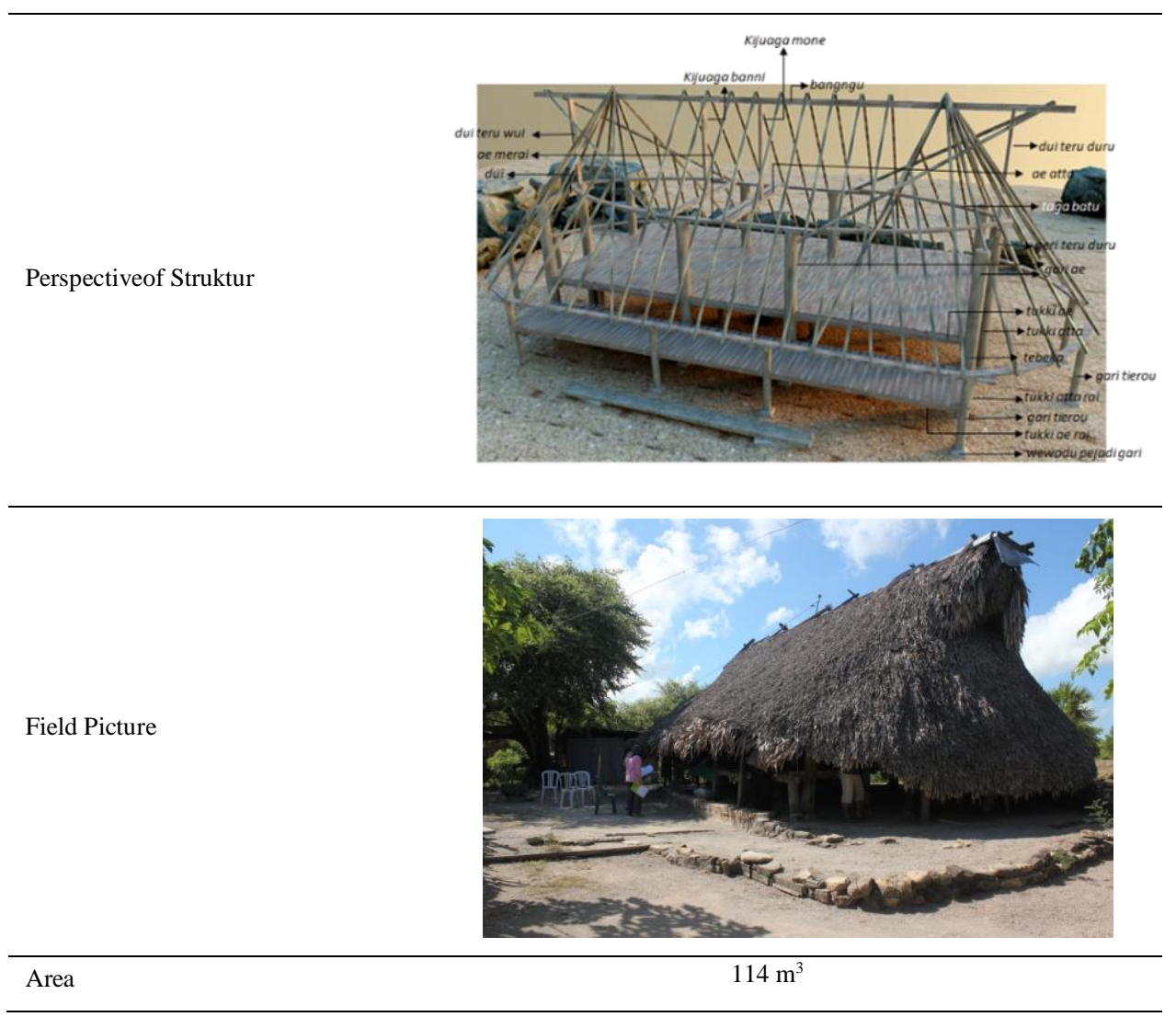

To analyze the thermal performance of the building, therefor the first specified $\mathrm{Tn}$ (neutral temperature) which is influenced by the average monthly temperatures. Based on the linier equation obtained that neutral temperature reached $25,85{ }^{\circ} \mathrm{C}$. The comfort zone range is $27,85-23,85^{\circ} \mathrm{C}$ with determined by the limit of $\mathrm{Tn} \pm 2{ }^{\circ} \mathrm{C}$ (Figure 5). Comparison between of indoor and outdoor temperature shows both have the same pattern. From the comparison of primary data, the performance of the building was able to decrease the temperature in the room reached $0.88{ }^{\circ} \mathrm{C}$ compared to outdoor temperature (Table 3).

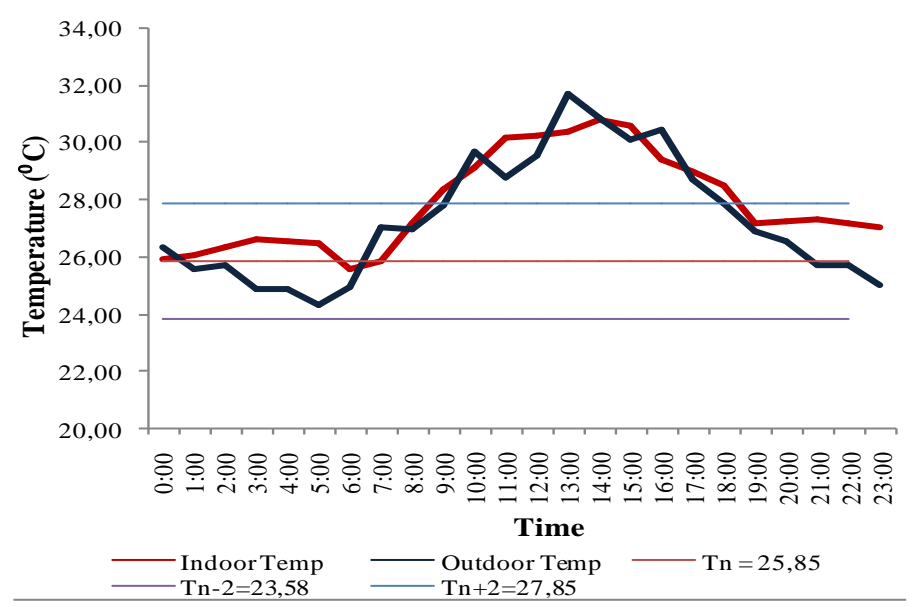

Fig. 5. The fluctuation of indoor and outddoor temperature. 
Table 3. Comparasion between indoor and outdoor comfort.

\begin{tabular}{lllll}
\hline Temperature & $\begin{array}{l}\text { Lenght of Comfort } \\
\text { duration (hours) }\end{array}$ & $\begin{array}{l}\text { Lenght of Uncomfort } \\
\text { duration (hours) }\end{array}$ & $\begin{array}{l}\text { Temperature } \\
\text { Maximum } \\
\left({ }^{\circ} \mathrm{C}\right)\end{array}$ & $\begin{array}{l}\text { Deference } \\
\text { of Tmax } \\
\left({ }^{\circ} \mathrm{C}\right)\end{array}$ \\
\hline Indoor & 14 & 10 & 30,80 & 0,88 \\
Outdoor & 15 & 9 & 31,68 & 0,88 \\
\hline
\end{tabular}

Comfort zone occurs in the afternoon until tomorrow morning. While the uncomfortable zone occurs in the morning until the afternoon. Therefor it can be said that comfort zone duration occurs for $58 \%$ of the daily time. In figure 6 shows that the duration comfortably indoors going for 14 hours in a day.

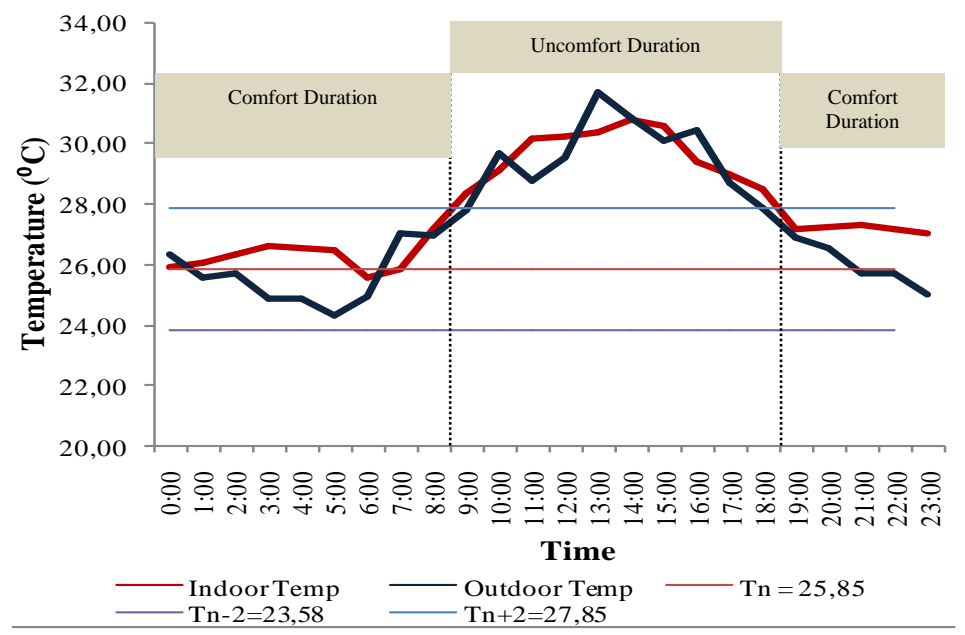

Fig. 6. Comfort and discomfort duration of thermal.

This study attempts to analyze other aspects that should be taken into account in evaluating the effectiveness of the performance of traditional buildings, named the occupancy pattern. The primary data of occupancy pattern, conducted by field observations with in-depth interview method with occupants. Traditional savu people generally works as farmers. As an agricultural society, most of the daily time spent on doing outdoor activities (farmed). Indoor activities occurs in the evening until tomorrow morning. At the time of time farming, ammu hawu only inhabited by 1-2 persons: the women who keep the house or keep their child. The observation data of occupancy patterns listed in Table 4.

Tabel 4. Daily Occupancy Pattern.

\begin{tabular}{|c|c|c|}
\hline Time & Activities & Occupancy \\
\hline $0: 00$ & Take a rest & Occupied \\
\hline $1: 00$ & Take a rest & Occupied \\
\hline 2:00 & Take a rest & Occupied \\
\hline 3:00 & Take a rest & Occupied \\
\hline 4: 00 & Take a rest & Occupied \\
\hline 5:00 & Take a rest & Occupied \\
\hline 6: 00 & Cooking & Occupied \\
\hline $7: 00$ & Outdoor activities & Unoccupied \\
\hline 8:00 & Outdoor activities & Unoccupied \\
\hline 9:00 & Outdoor activities & Unoccupied \\
\hline 10:00 & Outdoor activities & Unoccupied \\
\hline
\end{tabular}




\begin{tabular}{clc}
\hline 11:00 & Outdoor activities & Unoccupied \\
\hline 12:00 & Outdoor activities & Unoccupied \\
\hline 13:00 & Outdoor activities & Unoccupied \\
\hline 14:00 & Outdoor activities & Unoccupied \\
\hline 15:00 & Outdoor activities & Unoccupied \\
\hline 16:00 & Outdoor activities & Unoccupied \\
\hline 17:00 & Outdoor activities & Unoccupied \\
\hline 18:00 & Outdoor activities & Unoccupied \\
\hline 19:00 & Family time, take a rest, dinner time & Occupied \\
\hline 20:00 & Family time, take a rest, dinner time & Occupied \\
\hline 21:00 & Family time, take a rest, dinner time & Occupied \\
\hline 22:00 & Family time, take a rest, dinner time & Occupied \\
\hline $23: 00$ & Family time, take a rest, dinner time & Occupied \\
\hline
\end{tabular}

It is known that the occupied pattern of building Ammu Hawu, occurs from 18:00 in the afternoon, until 6 am the next morning. If it is associated with the duration of the comfort zone duration, seen that the duration of the dominant comfort zone occurs when the building occupied. From calculating duration time comfortable based on the neutral temperature threshold is 14 , note that only 2 hours building not inhabited. This means that buildings can be said to live in comfortable 79 \%. This is because from 19:00 - 06:00 pm the occupant inhabbitance the house. Room temperature in buildings fall into the category of the comfort zone (Figure 7). This is in line with the theories of anthropology which is very traditional residential believes that it is the fruit of the human mind that is ideal for occupancy because considering the conditions of the surrounding environment.

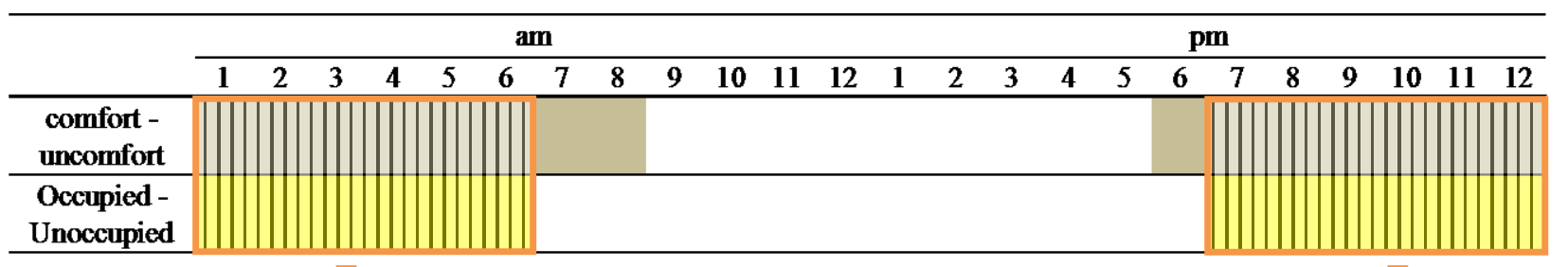

$79 \%$ of the comfort time occurred when the inhabitant were in the building
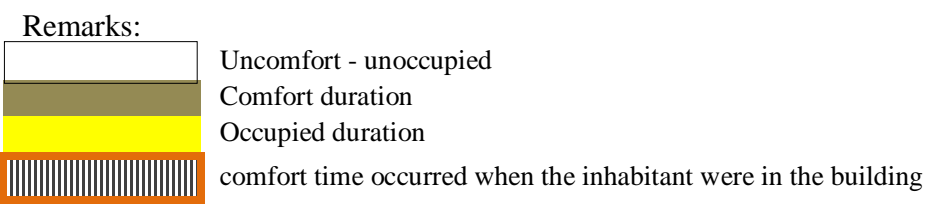

Fig. 7. Connectedness between duration of indoor comfort zone and duration of occupied.

\section{Conclusion}

The study found that performance Ammu Hawu house is good enough. It can be show from the length of the duration comfortably, that happens when the house is occupied. The result of measurement linear equation which using to determine the neutral temperature shows that, Ammu Hawu was daily comfortable conditions for 14 hours (58\%). Out of these 14 hour comfortable conditions, $79 \%$ of the time occurred when the inhabitant were in the building. Future house design ideally capable of creating the comfort duration in accordance with occupant patterns in the future. 


\section{Acknowledgment}

I would like to say thanks to Research Station For Housing on Region II Denpasar - Ministry of Public Work, that have financed the study with funds from the APBN year 2013. I would like to thanks also Lab. Sains \& Teknologi Arsitektur - Institute Teknologi Sepuluh November Surabaya.

\section{References}

Anderson, R. C., Keefer, D. R., Myers, O. E., Anderson, R. C., Keefer, D. R., \& Myers, O. E. (1972). Atmospheric Pressure and Temperature Changes During the 7 March 1970 Solar Eclipse. Journal of the Atmospheric Sciences, 29(3), 583-587. https://doi.org/10.1175/15200469(1972)029<0583:APATCD>2.0.CO;2

BMKG Kupang. (2012). Iklim Mikro Kabupaten Sabu Raijua.

Brager, G. S., \& de Dear, R. (2001). Climate, comfort, \& natural ventilation: a new adaptive comfort standard for ASHRAE standard 55. Retrieved from http://www.escholarship.org/uc/item/2048t8nn

Damayanti, D. P., Kasuma, I. P. A. W., \& Suprijanto, I. (2013). Mengenal Lebih Dekat Arsitektur Savunese. In Prosiding Seminar Jelajah Arsitektur Nusantara. Medan.

Handoko. (1993). Klimatologi Dasar. Bogor: Pustaka Jaya.

Humphreys, M. A., \& Nicol, J. F. (2000). Outdoor Temperature and Indoor Thermal Comfort: Raising the Precision of the Relationship for the 1998 ASHRAE Database of Field Studies. ASHRAE TRANSACTION, 106(2), 485-492.

Kana, N. L. (1978). Dunia Orang Sawu. Universitas Indonesia.

Machon, M. (2007). Secondary Scholar Activity The Changes of Meteorological and Physical Quantities during Annular and Total Solar Eclipse. Cheb.

Sugiyono. (2003). METODE PENELITIAN BISNIS. Bandung: Alfabeta.

Suprijanto, I., \& Damayanti, D. P. (2009). Arsitektur Tradisional di NTT (Suatu Identifikasi Dalam Upaya Melestarikan Arsitektur Tradisional). In Proceeding Kolokium 2009. Bandung.

UU 52/2008. UU Pembentukan Kabupaten Sabu Raijua NTT, Pub. L. No. UU 52/2008 (2008). 

-This page intentionally left blank-

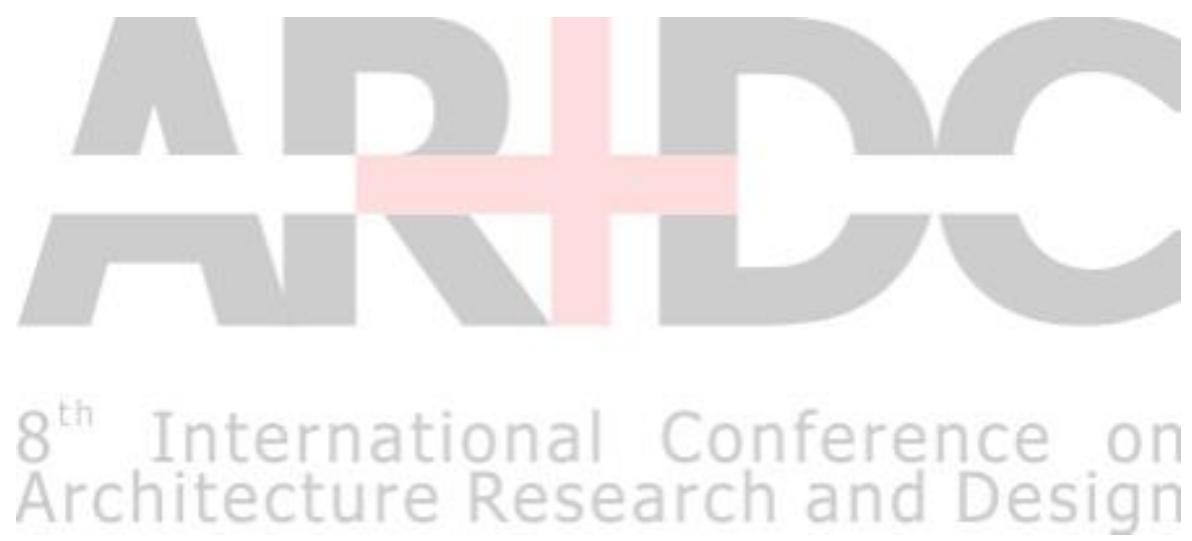

